\title{
Assessing the accuracy of a polymerase chain reaction test for Ichthyophonus hoferi in Yukon River Chinook salmon Oncorhynchus tshawytscha
}

\author{
Christopher M. Whipps ${ }^{1, *}$, Tamara Burton ${ }^{2}$, Virginia G. Watral ${ }^{1}$, Sophie St-Hilaire ${ }^{3}$, \\ Michael L. Kent ${ }^{1}$ \\ ${ }^{1}$ Center for Fish Disease Research, Department of Microbiology, 220 Nash, Oregon State University, Corvallis, \\ Oregon 97331-3804, USA \\ ${ }^{2}$ Alaska Department of Fish and Game, Division of Commercial Fisheries, 333 Raspberry Road, Anchorage, \\ Alaska 99518, USA \\ ${ }^{3}$ Department of Biological Sciences, Idaho State University, Pocatello, Idaho 83209, USA
}

\begin{abstract}
Ichthyophonus hoferi Plehn \& Mulsow, 1911, is a cosmopolitan, protistan pathogen of marine fishes. It is prevalent in mature returning Chinook salmon Oncorhynchus tshawytscha in the Yukon River watershed, and may be associated with prespawning mortality. We developed and evaluated a polymerase chain reaction (PCR) test for $I$. hoferi using primers specific to the parasite's small subunit rDNA. The test has a minimum detection limit of approximately $10^{-5}$ parasite spores per reaction and does not cross-react with the closely related salmon parasites Dermocystidium salmonis or Sphaerothecum destruens. Sensitivity and specificity of the PCR test used on somatic muscle and heart tissue for detecting infected fish were determined using 334 Chinook salmon collected from the Yukon River at 2 locations (Tanana and Emmonak) in 2003 and 2004. The true infection status of the fish was determined by testing somatic muscle, heart and kidney tissue using histological evaluation, culture, and PCR. The severity of infection was grouped into 2 categories, light and heavy infection. The probability of detecting a heavily infected fish (sensitivity of the test) was generally much higher than the probability of detecting light infection, suggesting that more than one tissue and/or method should be used to accurately detect light or early infection by I. hoferi. The probability of correctly identifying a negative fish (specificity of the test) was always greater than $94 \%$ regardless of the tissue used, infection severity, sampling site or year of collection.
\end{abstract}

KEY WORDS: Ichthyophonus hoferi - Mesomycetozoea $\cdot$ Chinook salmon · Alaska $\cdot$ Polymerase chain reaction $\cdot$ Small subunit ribosomal DNA

\section{INTRODUCTION}

Ichthyophonus hoferi Plehn \& Mulsow, 1911 is a parasite that infects many marine fishes (McVicar 1999). Although previously thought to be a fungus, it is now considered related to the choanoflagellate parasites Dermocystidium salmonis Davis, 1947, and Sphaerothecum destruens Arkush, Mendoza, Adkison \& Hedrick, 2003 (Ragan et al. 1996). Recent molecular analyses support the inclusion of all 3 species in the class Mesomycetozoea, although I. hoferi belongs to a different order and family (Ichthyophonida: Ichthyophonae) (Arkush et al. 2003). I. hoferi infects many organs in the host fishes, but the primary target tissue for the parasite in Yukon River Chinook salmon is the heart muscle. As the infection progresses, the parasite is disseminated to other visceral organs and the somatic muscle tissue (McVicar 1999, Kocan et al. 2004). The parasite has also been reported in the blood of some infected fishes (McVicar 1999). 
The disease caused by Ichthyophonus hoferi is of economic significance, because epizootics have resulted in mass mortality of commercial fish species such as Atlantic herring Clupea harengus Linnaeus, 1758 (McVicar 1999) and Pacific herring C. pallasi Valenciennes, 1847 off the coast of Alaska (Marty et al. 1998) and Washington (Hershberger et al. 2002). Salmonids are also susceptible to this parasite (Jones \& Dawe 2002, Schmidt-Posthaus \& Wahli 2002). Kocan et al. (2004) conducted an extensive, multi-year survey of $I$. hoferi in Chinook salmon Oncorhynchus tshawytscha (Walbaum, 1792) from the Yukon River from 1999 to 2003. They observed a trend in which fish had approximately 23 to $27 \%$ infection prevalence at Emmonak River Mile (RM) 24, near (i.e. 24 miles or $38 \mathrm{~km}$ from) the mouth of the river followed by an increase in prevalence at mid-river (RM 730 to 1230 ) to approximately 34 to $43 \%$. At Whitehorse Rapids, further up the river (RM 1745), prevalence of infection decreased to approximately 15 to $17 \%$. These data led Kocan et al. (2004) to suggest that $I$. hoferi may be associated with prespawning mortalities in this fishery.

Currently, Ichthyophonus hoferi is diagnosed by one of 3 methods: wet-mount squash preparations of muscle, viscera or heart; histology; and explant culture (McVicar 1999). The latter has been considered the most sensitive of these methods (Rahimian \& Thulin 1996, Kocan et al. 1999, 2004). A method which has become a routine diagnostic tool for many fish pathogens (Cunningham 2002), and is potentially much more sensitive than explant culture, is the polymerase chain reaction (PCR), which targets the DNA of the pathogen. There are certain advantages of PCR over culture and other diagnostic techniques: (1) samples do not require any special incubation or handling after collection, (2) PCR diagnosis requires less time, (3) large numbers of samples can be tested relatively easily using PCR, (4) diagnosis can be made even if the organism is no longer viable, (5) the DNA sequence generated using PCR can be used for taxonomic separations of morphologically similar strains or species of the organism. Indeed, using small subunit (SSU) rDNA, Criscione et al. (2002) differentiated between $I$. hoferi infecting rockfish (Sebastes spp.) and I. hoferi infecting Yukon River Chinook salmon and Pacific herring.

There are some disadvantages in using PCR. For example, PCR detects fragments of DNA, and thus will detect both living and dead parasites, making the status of the infection difficult to discern. Likewise, many PCR tests are not quantitative, and thus the severity of infection cannot be assessed in this manner. Because of the inherently sensitive nature of $\mathrm{PCR}$, precautions must be taken to minimize the likelihood of cross- contamination between samples which could result in false positives. Despite these drawbacks, the advantages of PCR make it an excellent tool for diagnosis of fish diseases.

The objectives of this study were to develop a PCR test, specific to the SSU rDNA sequence of Ichthyophonus hoferi, to determine the sensitivity and specificity of this test to detect infected Yukon River Chinook salmon, and to evaluate PCR as a potentially non-lethal diagnostic method for detection of $I$. hoferi.

\section{MATERIALS AND METHODS}

Primer design. Clustal X (Thompson et al. 1997) was used to align the SSU rDNA sequence of Ichthyophonus hoferi (GenBank Accession Nos. U25637, AF467785-802) to numerous taxonomically and phylogenetically related species of choanoflagellates using the phylogeny of Arkush et al. (2003) as a guideline. Several additional sequences for alignment were selected from basic local-alignment search-tool (BLAST) (Altschul et al. 1990) matches on GenBank (GB). Finally, SSU rDNA sequences from Oncorhynchus kisutch (GB AF030250) and O. mykiss (GB AF308735) were used as outgroups in this complete alignment of 42 DNA sequences. Primers were selected by eye to regions 18 to 20 nucleotides in length, showing complementarity to I. hoferi SSU rDNA, but compared to all of the other sequences in our alignment had at least 2 mismatches overall and always 1 mismatch in the 3prime end. Primers were then evaluated using the online Oligo Analysis \& Plotting Tool (Operon Biotechnologies) for appropriate melting temperatures, $\%$ guanine and cytosine content, and whether they formed homodimers or stemloops. Acceptable primers were then subjected to a BLAST search against all DNA sequences in GenBank to verify their specificity to $I$. hoferi. Considering the length of the predicted products, we evaluated 7 possible primer combinations using 2 forward, 2 reverse, and existing primers of Criscione et al. (2002). From our preliminary data, we selected the single primer combination in following subsection for further analysis.

Polymerase chain reaction. Approximately $50 \mathrm{mg}$ of ethanol-fixed tissue was placed in a $1.5 \mathrm{ml} \mathrm{mi-}$ crofuge tube and nucleic acid extractions were conducted using the DNeasy Tissue kit (QIAGEN). The Ichthyophonus hoferi-specific PCR primers Ich7f (5'GCT CTT AAT TGA GTG TCT AC-3') and Ich6r (5'CAT AAG GTG CTA ATG GTG TC-3') were used to amplify a 371 base pair (bp) fragment of the SSU rDNA under the following conditions. Reactions were prepared in $25 \mu$ volumes and consisted of $1 \times$ PCR buffer, $2.5 \mathrm{mM} \mathrm{MgCl}_{2}, 0.2 \mathrm{mM}$ dNTP, 25 pmol 
each primer, $0.025 \mathrm{U} \mathrm{\mu l}^{-1}$ Taq DNA polymerase and $2 \mu \mathrm{l}$ of template DNA. Reactions were carried out using MJ Research DNA Engine 200 for 35 cycles consisting of $94^{\circ} \mathrm{C}$ for $30 \mathrm{~s}, 60^{\circ} \mathrm{C}$ for $45 \mathrm{~s}, 72^{\circ} \mathrm{C}$ for $60 \mathrm{~s}$, preceded by an initial denaturation at $95^{\circ} \mathrm{C}$ for $3 \mathrm{~min}$, and followed by a final extension at $72^{\circ} \mathrm{C}$ for $7 \mathrm{~min}$. Products were visualized on an agarose gel stained with ethidium bromide.

Minimum detection limit. The number of parasite spores in $18 \mathrm{mg}$ of heavily infected heart tissue was estimated based on the number of spores observed histologically per square mm of a $5 \mu$ m-thick tissue section. Using the area of tissue and thickness we could estimate the number of spores within a given volume of tissue. Assuming a tissue density of $1 \mathrm{mg}$ $\mu^{-1}$, an average spore diameter of $147 \mu \mathrm{m}$, and an equal distribution of the parasite, we estimated the number of Ichthyophonus hoferi spores to be 24

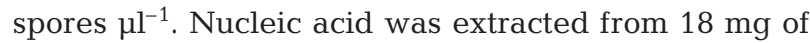
this tissue, yielding a DNA extract containing 4.4 spores $\mu \mathrm{l}^{-1}$. Seven 10 -fold serial dilutions were prepared using uninfected heart tissue as diluent. For each PCR reaction, $2.3 \mu \mathrm{l}$ of each dilution was used to yield a final spore concentration of $10,1,0.1 \ldots 10^{-6}$ spores per reaction. PCR was run on all dilutions in duplicate.

Sensitivity and specificity. The ability of the PCR test to detect infected and non-infected fish is referred to as the test's sensitivity and specificity, respectively. These were calculated using the following formulas: Sensitivity $=$ (no. of test-positive infected fish)/(no. of truly infected fish); Specificity $=$ (no. of test negative noninfected fish)/(no. of truly non-infected fish).

The 'true' infection status of a fish was determined by examining the results of all other tests performed on the fish with the exception of the PCR test being evaluated. If any of the tissues of a fish was positive by any of the other diagnostic tests used, the fish was categorized as infected with Ichthyophonus hoferi. Fish that were negative with all other tests except the one evaluated were considered negative.

The sensitivity and specificity of the PCR test at detecting Ichthyophonus hoferi in heart tissue, somatic muscle and blood of the fish was calculated for each field site and each year separately. This was done because samples were not collected in a similar manner between sites. Therefore, the true status of each fish was determined differently depending on the number of tests performed at each site. This permitted us to maximize the information collected at the different sites.

We also evaluated the ability of the PCR test to detect lightly versus heavily infected tissues separately. A fish was categorized as lightly infected with Ichthyophons hoferi if it only had 1 tissue infected with the parasite as determined by any method, and $\leq 1$ spore $\mathrm{mm}^{-2}$ tissue as determined by histological evaluation of 1 field. Tissues with greater than 1 parasite $\mathrm{mm}^{-2}$ were categorized as heavily infected.

The ability of the PCR test to detect infection at the tissue level was determined by comparing the results of the PCR test on the heart tissue with the heart histology and culture results (when available). Confidence intervals were calculated for all sensitivity and specificity estimates using the efficient-score method, corrected for continuity (Newcombe 1998)

The PCR test was also tested for specificity against 2 other related salmonid pathogens present in the Pacific NW (i.e. Dermocystidium salmonis and Sphaerothecum destruens). We tested 2 samples of D. salmonis from heavily infected gill tissue of Chinook salmon from Oregon, and 1 sample of $S$. destruens from Chinook salmon from California using the PCR primers for Ichthyophonus hoferi.

Field samples in 2003 at Tanana. A total of 100 Chinook salmon were collected at the Tanana village fishwheel (RM 695), from July 1 to 6, 2003. A sample of somatic muscle, kidney and heart from each fish were preserved in $10 \%$ buffered formalin for histology and $95 \%$ ethanol for PCR testing. The ethanol-fixed tissue was processed for PCR using the method described in earlier subsection. Histological samples were processed using standard techniques and stained with hematoxylin and eosin. The number of parasites in the heart, kidney and muscle were estimated by examination of tissue sections, and counting the number of spores $\mathrm{mm}^{-2}$.

Field samples in 2004 at Tanana. A total of 150 fish were collected from July 2 to 5, 2004, at the Tanana Village fish wheel (RM 695). Muscle and heart were collected for histology and PCR as described above, as well as for culture. Tissues were cultured for $14 \mathrm{~d}$ at $12^{\circ} \mathrm{C}$ in Eagle's minimal essential media 5 (5\% fetal bovine serum) with $100 \mathrm{mg} \mathrm{ml}^{-1}$ gentamycin and streptomycin and $100 \mathrm{IU} \mathrm{ml}^{-1}$ penicillin.

In addition, blood was collected by caudal vein puncture, kept on dry ice (temperature not monitored), and sent to the laboratory for storage at $-70^{\circ} \mathrm{C}$. A $10 \mu \mathrm{l}$ aliquot of blood was used for DNA extraction, and PCR was conducted as described above. We tested 12 blood samples from Chinook salmon collected at Tanana; 4 from uninfected fish, 4 from fish with light infections and 4 from heavily infected fish.

Field samples in 2004 at Emmonak. A total of 104 Chinook salmon were collect at this site (RM 24) between June 6 and July 15, 2004. Tissue samples were collected as described above except that only heart tissues were cultured. Blood was collected as described above and PCR was conducted on 104 samples. 


\section{RESULTS}

The primer pair Ich7f/Ich6r was highly specific to Ichthyophonus hoferi and did not cross-react with 2 closely related salmon parasites, Dermocystidium salmonis and Sphaerothecum destruens (Fig. 1). Furthermore, the PCR test also had a very low minimum detection limit. Calculations based on dilutions of infected heart tissue estimated this minimum limit as $10^{-5}$ spores per reaction (Fig. 2).

The overall prevalence of Ichthyophonus hoferiinfected fish at the 2 samplings ranged from 14.1 to $44.1 \%$ when all diagnostic methods and tissues were

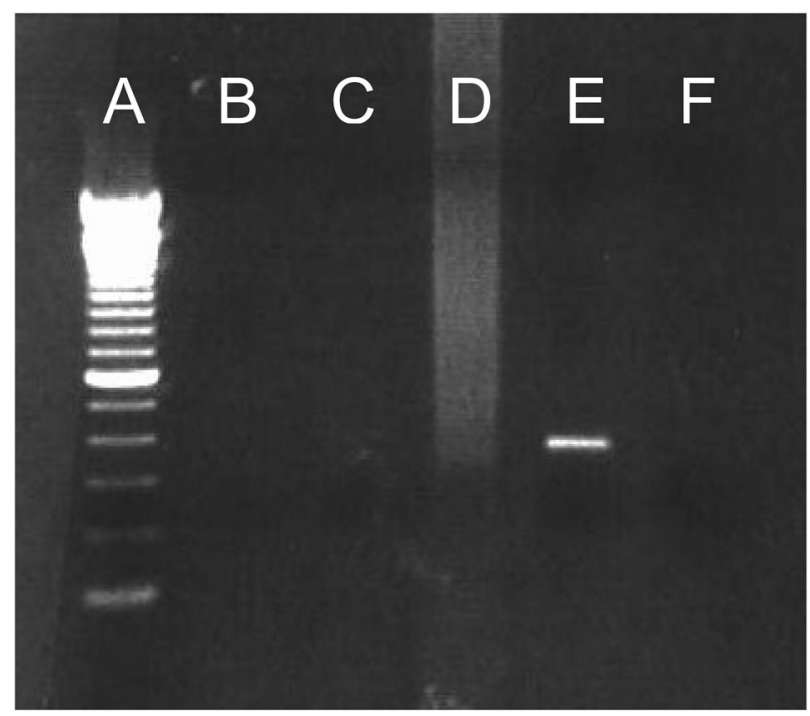

Fig. 1. Specificity of Ichthyophonus hoferi PCR test. Test does not react with Dermocystidium salmonis (heavy infected gills) or Sphaerothecum destruens (rosette agent). Lane A: $100 \mathrm{bp}$ DNA ladder; B: D. salmonis 1; C: D. salmonis 2; D: S. destruens; E: Ichthyophonus hoferi; F: uninfected Chinook salmon Oncorhynchus tshawytscha (negative control) considered (Table 1). Infection prevalence was much lower in 2004 than in 2003, regardless of the location at which fish were collected.

At the tissue level (heart muscle alone), PCR was very sensitive and specific for detecting Ichthyophonus hoferi infection (Table 2). Compared to histology and culture results, PCR sensitivity was consistently above $90.9 \%$ and as high as $100 \%$ in the fish from Emmonak in 2004. Specificity was also very high, ranging from 91.2 to $98.9 \%$ in different years (Table 2).

At the host level, sensitivity of the PCR test for the somatic muscle ranged between 84 and $100 \%$ for fish considered to have heavy infection; however, the sensitivity of this test for detection of light infection was considerably lower (Table 3) ranging between 25 and $75 \%$ depending on sampling site and year of collection.

The sensitivity of the PCR test for the heart tissue was high for fish considered to have heavy infection (range between 89 and $100 \%$ : Table 3). The sensitivity of this test when detecting light infection in heart tissue was lower (range between 50 and $100 \%$ ), but higher than its sensitivity when using somatic muscle to detect lightly infected fish (Table 3). Specificity of this test was consistently above $94 \%$ (Table 3 ) regardless of tissue tested (somatic muscle or heart tissue), and when or where the samples were collected or which laboratory tested them.

Sensitivity of the PCR test on blood was very poor at $8.7 \%$ (95\% confidence interval of 0 to $60 \%$ ). Only 2 of the 23 infected fish tested positive by this method. Nonetheless, specificity was 100\% (95\% CI $=95$ to $100 \%)$; there were no false-positive fish.

\section{DISCUSSION}

The PCR test for Ichthyophonus hoferi assessed in this study was found to be very specific for the parasite. Sensitivity of the test varied depending on the severity of infection, the tissue tested and the year and location of fidh collection (Table 3). The test had the highest sensitivity when cardiac muscle was used and fish were heavily infected.

PCR tests generally have very low minimum detection limits, and thus are inherently sensitive diagnostic tests. The limit of the PCR in this study was consistent with that reported for other parasites of fishes (Cunningham 2002). The serial dilutions tested in this study estimated the detection limit at $10^{-5}$ spores per reaction. This is theoretically feasible as a spore of Ichthyophonus hoferi contains many individual cells (McVicar 1999). In addition, individual
Fig. 2. Ichthyophonus hoferi infecting Oncorhynchus tshawytscha. Minimum detection limit of $I$. hoferi PCR test. Serial, log dilutions of infected heart tissue were made, and estimated numbers of spores per PCR are shown at top of each lane. Results (+: positive; -: negative) indicated that test is capable of detecting the parasite in tissue at estimated density of $10^{-5}$ spores 
Table 1. Ichthyophonus hoferi infecting Oncorhynchus tshawytscha. Prevalence of $I$. hoferi in Yukon River Chinook salmon collected at Tanana and Emmonak using different diagnostic tests. Values are no. fish positive/no. examined (mean \% positive; $95 \%$ CI). na: not available

\begin{tabular}{|c|c|c|c|}
\hline Diagnostic test & Tanana 2003 & Tanana 2004 & Emmonak 2004 \\
\hline \multicolumn{4}{|l|}{ PCR } \\
\hline Heart & $34 / 100(34.0 ; 25-44)$ & 11/100 (11.0; 6-19) & $23 / 104(22.1 ; 15-32)$ \\
\hline Muscle & $32 / 100(32.0 ; 23-42)$ & $11 / 150(7.3 ; 4-13)$ & $11 / 104(10.6 ; 6-19)$ \\
\hline Kidney & 25/100 (25.0; 17-35) & na & na \\
\hline \multicolumn{4}{|l|}{ Histology } \\
\hline Heart & $27 / 84(32.1 ; 23-43)$ & $11 / 149(7.4 ; 4-13)$ & 15/101 (14.9; 9-24) \\
\hline Muscle & $11 / 83(13.3 ; 7-23)$ & $8 / 149(5.4 ; 3-11)$ & $5 / 101(5.0 ; 2-12)$ \\
\hline Kidney & 20/84 (23.8; 15-35) & na & na \\
\hline \multicolumn{4}{|l|}{ Culture } \\
\hline Heart & na & 17/150 (11.3; 7-18) & 16/90 (17.8; 11-28) \\
\hline Muscle & na & 14/150 (9.3; 5-15) & na \\
\hline $\begin{array}{l}\text { All tests } \\
\text { combined }^{\mathrm{a}}\end{array}$ & 37/84 (44.1; 33-55) & 14/99 (14.1; 8-23) & $19 / 87(21.8 ; 14-32)$ \\
\hline
\end{tabular}

Table 2. Oncorhynchus tshawytscha infected with Ichthyophonus hoferi. Sensitivity and specificity of PCR on heart muscle to identify infected heart. True infection status of heart tissue determined by histological evaluation and culture. Tissue that was positive by either technique was considered infected. No culture was prepared for Tanana samples in 2003. Values are mean \% (95\% CI)

\begin{tabular}{|c|c|c|c|}
\hline \multicolumn{2}{|l|}{ Sample } & \multirow{2}{*}{$\begin{array}{c}\text { Sensitivity } \\
96.3(79-100)\end{array}$} & \multirow{3}{*}{$\begin{array}{c}\text { Specificity } \\
91.2(80-97) \\
98.9(93-100)\end{array}$} \\
\hline Tanana & 2003 & & \\
\hline & 2004 & $90.9(57-100)$ & \\
\hline Emmonak & 2004 & $100.0(80-100)$ & $95.8(87-99)$ \\
\hline
\end{tabular}

cells contain multiple copies of the small subunit rDNA (Hillis \& Dixon 1991), the target of our PCR primers. This suggests that the test is likely to detect the presence of prespore stages and lighter infection when the appropriate tissue is sampled.
Despite a very low minimum detection limit, we determined that severity of infection has a large influence on the sensitivity of this PCR test. At the level of the host, selecting the appropriate organ for testing is critical as Ichthyophonus hoferi may not be uniformly distributed within the fish. Although the somatic muscle, kidney and visceral organs may be infected, the target tissue for I. hoferi in Yukon River Chinook salmon appears to be the cardiac muscle (Kocan et al. 2004). The findings of this study are consistent with this observation, as the organ tissue with the highest parasite prevalence (as determined by PCR histology and culture) was the heart tissue (Table 1). The PCR test had the highest sensitivity when applied to the heart tissue (Table 3). If only 1 tissue is sampled, it should be cardiac muscle in order to increase the probability of detecting the parasite.

Intuitively, the likelihood of misdiagnosing an infected fish is inversely related to the number of parasites (severity of infection) in the fish, and directly proportional to the amount of tissue(s) sampled. As expected, light infection of Ichthyophonus hoferi was not detected as often as heavy infection when using PCR on a single tissue (Table 3). This observation was consistent for all tissues at all sampling sites, with the exception of the cardiac muscle samples collected at Emmonak in 2004, where sensitivity was always $100 \%$. Testing a single tissue from a fish may not reliably detect all infections, especially if somatic muscle tissue is used from lightly infected fish. This is probably due to the lack of parasite dissemination into the somatic muscle in lighter infection (Kocan et al. 2004). Thus, although this tissue can be collected from fish in a non-lethal manner, more than half of the lightly

Table 3. Sensitivity and specificity of the Ichthyophonus hoferi PCR test on somatic or heart muscle to identify the infection status of fish. The sensitivity of the PCR used on muscle to detect lightly and heavily infected fish was calculated separately. Values are mean \% $(95 \% \mathrm{CI})$

\begin{tabular}{|c|c|c|c|c|c|}
\hline \multirow[t]{2}{*}{ Tissue } & & \multirow[b]{2}{*}{ Combined } & \multirow{2}{*}{$\begin{array}{l}\text { Sensitivity } \\
\text { Light }\end{array}$} & \multirow[b]{2}{*}{ Heavy } & \multirow[t]{2}{*}{ Specificity } \\
\hline & & & & & \\
\hline \multicolumn{6}{|l|}{ Somatic } \\
\hline \multirow{2}{*}{ Tanana } & 2003 & $79.4(62-91)$ & $50.0(18-83)$ & $88.5(69-97)$ & 94.0 (82-98) \\
\hline & 2004 & $50.0(28-72)$ & $0(0-44)$ & $76.9(46-94)$ & $100.0(95-100)$ \\
\hline Emmonak 2 & 2004 & $47.8(27-69)$ & $25.0(7-57)$ & $72.7(39-93)$ & $100.0(94-100)$ \\
\hline \multicolumn{6}{|l|}{ Heart } \\
\hline \multirow[t]{2}{*}{ Tanana } & 2003 & $83.3(67-93)$ & $42.9(12-80)$ & 93.1 (76-99) & $97.9(88-100)$ \\
\hline & 2004 & $78.6(49-94)$ & $50.0(14-86)$ & $100.0(60-100)$ & $100.0(95-100)$ \\
\hline Emmonak 2 & 2004 & $100.0(80-100)$ & $100.0(52-100)$ & $100.0(73-100)$ & 95.8 (87-99) \\
\hline
\end{tabular}


infected fish will not be detected. For heavily infected fish, this is less problematic (Table 3).

Although McVicar (1999) reported that Ichthyophonus hoferi occasionally occurs in blood, we rarely detected the parasite in blood, with blood PCR revealing only $8.7 \%(2 / 23)$ of infected fish in our sample as positive. Our findings were consistent regardless of the preservation technique used for the blood (data not shown). Thus, although blood can be collected from fish in a non-lethal manner, the PCR test is unlikely to correctly identify infected fish using blood.

Because PCR tests require very little tissue to accurately detect infection if present, distribution of the parasite within individual tissues will also influence the sensitivity of the test. Herein, we tested a $50 \mathrm{mg}$ piece of each tissue by $\mathrm{PCR}$, which is a very small amount considering that a Yukon River Chinook salmon commonly weighs about $10 \mathrm{~kg}$. Indeed, Ichthyophonus hoferi commonly elicits a granulomatous response, resulting in an infection which is focal or multifocal, rather than diffuse (McVicar 1999). Thus, it is possible that by sampling a small portion of a single organ, the parasite is not sampled and therefore not detected. To evaluate the performance of the PCR test at the tissue level, the sensitivity and specificity of the test were calculated using the true infection status of the tissue alone (as opposed to the entire fish). Results indicate that despite the multifocal nature of $I$. hoferi infection the PCR test was accurate at detecting infection in the heart when that tissue was deemed infected by culture and/or histology (sensitivity 90.6 to $100 \%$ : Table 2). The reduced sensitivity (78.6 to $100 \%$ ) when the PCR results on the heart were used to indicate the infection status of the fish (as opposed to tissue alone: Table 3) suggests that a small percentage of infected fish may not have sufficient parasite loads in the heart tissue to be detected. Despite these few individuals, however, the heart appeared to be the best tissue to sample (if only 1 tissue is used) to detect infection.

It may be possible to improve the sensitivity of the sampling scheme by sampling more than 1 tissue and testing multiple pieces of each tissue. Nonetheless, there has to be a balance between the cost of sampling in such a manner and the additional information this type of sampling provides. However, if the objective of a study is to detect light Ichthyophonus hoferi infection then we recommend that another tissue in addition to the heart be sampled. For example, in this study we found that by testing somatic muscle as well as heart, we identified most infected fish.

Differences in sensitivity and specificity of our test between sites and years could be due to a number of factors: (1) different individuals conducted the sampling at different sites, and different laboratories performed the diagnostic tests on samples from different years. (2) The severity of infection in this study was separated into only 2 broad categories, which may not have included all the different levels of infection. As noted above, the severity of infection was a factor that influenced the sensitivity of the test. If this varied and was not covered by our classification scheme it would account for some of the discrepancies in the data. It was not possible to quantify the level of infection more accurately given the available data. (3) A factor which may have contributed to the difference in the sensitivity results was the lower prevalence of Ichthyophonus hoferi in 2004 (Table 1). Lower prevalence of infected fish in 2004 meant that sensitivity estimates were not as statistically reliable because they were based on small sample sizes (few infected fish). This was reflected in the large confidence intervals for these prevalence data. Given these limitations to the sampling, the differences in the sensitivity between sites and years were somewhat expected.

Regardless of the tissue tested, specificity of the Ichthyophonus hoferi PCR test was always high, i.e. uninfected fish were correctly diagnosed by this method. To ensure that the PCR test did not crossreact, 2 closely related parasites of Chinook salmon, Dermocystidium salmonis and Sphaerothecum destruen, were also tested. The PCR test did not detect these parasites; however, we were not able to check the specificity of the PCR primers against all known parasites. For example, I. hoferi may comprise a species complex (Criscione et al. 2002), and thus the PCR test is likely to react with other members of this complex. In future studies, should there be a departure from the expected impact of the parasite related to the results of the PCR, it would be advisable to confirm the infection status in a proportion of fish using an alternate technique such as explant culture or DNAsequencing.

The PCR test appears to be as sensitive (or more sensitive) at detecting tissue-level infection as histology or culture (Table 1). This is consistent with PCR tests developed to detect other pathogens of fishes, whereby these were shown to be more sensitive than conventional methods, especially for detection of less severe infection (Docker et al 1997, Hervio et al. 1997, Palenzuela \& Bartholomew 2002). In the present study, a few fish tested positive for Ichthyophonus hoferi using PCR but negative using all other tests. These may represent false-positives, although specificity of the PCR was always high despite these. (A falsepositive would mean that the PCR yielded a positive result in the absence of parasite DNA.) Given the high overall specificity, this seems unlikely. However other, more likely scenarios could explain these results. For example, 3 of the fish were sampled immediately after sampling of a heavily infected fish (apparent from our 
sampling number sequence), suggesting possible field or laboratory contamination. Alternatively, the PCR test may be more sensitive than histological evaluation and culture, and these may have been true infections that were only detected by PCR.

As Ichthyophonus hoferi has been implicated as the cause of prespawning mortality in Yukon River Chinook salmon (Kocan et al. 2004), PCR may be useful for determining the fate of infected fish. We found that the use of somatic muscle, not blood, is the most effective method of non-lethal detection of $I$. hoferi, although lighter infection may go undetected. The most sensitive test to detect the parasite in Yukon River Chinook salmon is PCR of the cardiac muscle, the primary site of infection. Ultimately, selection of the appropriate diagnostic method will vary, depending on the goal of each individual study.

Acknowledgements. For assistance with collections and diagnostic testing we thank the Alaska Department of Fish and Game field sampling and laboratory personnel. N. Starkey, S. McNeil, L. Dubois, A. Stiassny, B. Whitmore, G. Weekly, J. Baumer, J. Eiler, E. Kahler, W. Evans and K. Griese. Specimens of Dermocystidium salmonis were provided by R. Holt, Oregon Department of Fish and Wildlife, and specimens of Sphaerothecum destruens by K. Arkush, University of California, Bodega Bay, California. Thanks to B. Keafer for a critical review of this manuscript.

\section{LITERATURE CITED}

Altschul SF, Gish W, Miller W, Myers EW, Lipman DJ. (1990) Basic local alignment search tool. J Mol Biol 215:403-410

Arkush KD, Mendoza L, Adkison MA, Hedrick RP (2003) Observations on the life stages of Sphaerothecum destruens n.g., n.sp., a mesomycetozoen fish pathogen formally referred to as the rosette agent. J Eukaryot Microbiol 50: $430-438$

Criscione CD, Watral V, Whipps CM, Blouin MS, Jones SRM, Kent ML (2002) Ribosomal DNA sequences indicate isolated populations of Ichthyophonus hoferi in geographic sympatry in the northeastern Pacific Ocean. J Fish Dis 25: 575-582

Cunningham C (2002) Molecular diagnosis of salmonid diseases. Kluwer Academic Publishers, Dordrecht

Docker MF, Devlin RH, Richard J, Khattra J, Kent ML (1997) Sensitive and specific polymerase chain-reaction assay for detection of Loma salmonae (Microsporea). Dis Aquat Org

Editorial responsibility: Wolfgang Körting,

Hannover, Germany
29:41-48

Hershberger PK, Stick K, Bui B, Carroll C and 7 others (2002) Incidence of Ichthyophonus hoferi in Puget Sound fishes and its increase with age of pacific herring. J Aquat Anim Health 14:50-56

Hervio DML, Kent ML, Khattra J, Sakanari J, Yokoyama H, Devlin RH (1997) Taxonomy of Kudoa species (Myxosporea), using a small-subunit ribosomal DNA. Can J Zool 75:2112-2119

Hillis DM, Dixon MT (1991) Ribosomal DNA: molecular evolution and phylogenetic inference. Q Rev Biol 66:411-453

Jones SRM, Dawe SC (2002) Ichthyophonus hoferi Plehn and Mulsow in British Columbia stocks of Pacific herring, Clupea pallasi Valenciennes, and its infectivity to chinook salmon, Oncorhynchus tshawytscha (Walbaum). J Fish Dis 25:415-422

Kocan RM, Hershberger P, Mehl T, Elder N, Bradley M, Wildermuth D, Stick K (1999) Pathogenicity of Ichthyophonus hoferi for laboratory-reared Pacific herring Clupea pallasi and its early appearance in wild Puget Sound Herring. Dis Aquat Org 35:23-29

Kocan R, Hershberger P, Winton J (2004) Ichthyophoniasis: an emerging disease of Chinook salmon in the Yukon River. J Aquat Anim Health 16:58-72

Marty GD, Freiberg EF, Meyers TR, Wilcock J, Farver TB, Hinton DE (1998) Viral hemorrhagic septicemia virus, Ichthyophonus hoferi, and other causes of morbidity in Pacific herring Clupea pallasi spawning in Prince William Sound, Alaska, USA. Dis Aquat Org 32:15-40

McVicar AH (1999) Ichthyophonus and related organisms. In: Woo PTK, Bruno DW (eds) Fish diseases and disorders, Vol 3. Viral, bacterial and fungal infections. CABI Publishing, New York, p 661-687

Newcombe RG (1998) Two-sided confidence intervals for the single proportion: comparison of seven methods. Stat Med $17: 857-872$

Palenzuela O, Bartholomew JL (2002) Molecular tools for the diagnosis of Ceratomyxa shasta (Myxozoa). In: Cunningham CO (ed) Molecular diagnosis of salmonid diseases. Kluwer Academic Publishers, Dordrecht, p 285-298

Ragan MA, Goggins CL, Cawthorn RJ, Cerenius L and 5 others (1996) A novel clade of protistan parasites near the animal-fungal divergence. Proc Natl Acad Sci USA 93: 11907-11912

Rahimian H, Thulin J (1996) Epizootiology of Ichthyophonus hoferi in herring populations off the Swedish west coast. Dis Aquat Org 27:187-195

Schmidt-Posthaus H, Wahli T (2002) First report of Ichthyophonus hoferi infection in wild brown trout (Salmo trutta) in Switzerland. Bull Eur Assoc Fish Pathol 22: $225-228$

Thompson, JD, Gibson TJ, Plewniak F, Jeanmougin F, Higgins DG (1997). The ClustalX windows interface: flexible strategies for multiple sequence alignment aided by quality analysis tools. Nucleic Acids Res 24:4876-4882

Submitted: June 8, 2005; Accepted: August 10, 2005

Proofs received from author(s): December 15, 2005 